\title{
Analisis Kemampuan Siswa Kelas VIII dalam Menyelesaikan Soal Literasi Numerasi
}

\author{
Dekriati Ate, Yulius Keremata Lede \\ ${ }^{1,2}$ Program Studi Pendidikan Matematika, Sekolah Tinggi Keguruan dan Ilmu Pendidikan Weetebula, \\ Jl. Mananga Aba, Karuni, SBD, NTT, Indonesia \\ dekriati@gmail.com
}

\begin{abstract}
In the 21 st century, students are required to master the three skills, namely the quality of character, competence, and literacy. In order these skills to be achieved, the ability to think and reason is needed. One of literacy that closely related to the ability to thinks and reason is numeracy literacy. This research was conducted with the title: "Ability of Class VIII Junior High School Students in solving numeracy literacy questions". This research was conducted at St. Josef Freinadementz Junior High School, Kota District, Southwest Sumba Regency. The aim is to describe students' abilities in solving numeracy literacy problems. This research includes descriptive qualitative research, and it was carried out from July 2021 to September 2021 at SMP St. Josef Freinadementz, City District, Southwest Sumba Regency. The research subjects were 15 students of class VIII. Data were collected through numeracy literacy skills tests and interviews. The results showed that $73.3 \%$ of students were in the very poor category and $26.7 \%$ were in the less category, so it can be concluded that in general the students' ability in solving numeracy literacy questions is still low.
\end{abstract}

Keywords: Student skill, literacy, numeracy

\begin{abstract}
Abstrak
Di abad ke 21, siswa dituntut untuk menguasai ketiga kecakapan yaitu kualitas karakter, kompetensi dan literasi. Agar kecakapan tersebut dapat tercapai, diperlukan kemampuan berpikir dan bernalar. Salah satu literasi yang erat kaitannya dengan kemampuan berpikir dan bernalar adalah literasi numerasi. Penelitian ini dilakukan dengan judul: "Kemampuan Siswa SMP Kelas VIII dalam menyelesaikan soal literasi numerasi". Penelitian ini dilakukan di SMP St Josef Freinadementz, Kecamatan Kota, Kabupaten Sumba Barat Daya. Tujuannya adalah untuk mendeskripsikan kemampuan siswa dalam menyelesaikan soal literasi numerasi. Penelitian ini termasuk penelitian kualitatif deskriptif, dan dilaksanakan mulai dari bulan Juli 2021 sampai September 2021 di SMP St. Josef Freinadementz, Kecamatan Kota, Kabupaten Sumba Barat Daya. Subyek penelitian adalah siswa kelas VIII sebanyak 15 siswa. Data dikumpulkan melalui tes kemampuan literasi numerasi dan wawancara. Hasil penelitian menunjukkan 73,3\% siswa berada pada kategori kurang sekali dan 26,7\% berada pada kategori kurang, sehingga dapat disimpulkan bahwa secara umum kemampuan siswa dalam menelesaikan soal literasi numerasi masih rendah
\end{abstract}

Kata kunci: Kemampuan Siswa, Literasi, Numerasi

Copyright (c) 2022 Dekriati Ate, Yulius Keremata Lede

$\square$ Corresponding author: Dekriati Ate

Email Address: dekriati @gmail.com (Jl. Mananga Aba, Karuni, SBD, NTT, Indonesia)

Received 28 September 2021, Accepted 09 October 2021, Published 25 January 2022

\section{PENDAHULUAN}

Di abad ke 21, siswa dituntut untuk menguasai ketiga kecakapan yaitu kualitas karakter, kompetensi dan literasi. Agar kecakapan tersebut dapat tercapai, diperlukan kemampuan berpikir dan bernalar karena kemampuan ini dapat digunakan untuk memecahkan suatu masalah. Kemampuan ini berkaitan dengan kemampuan literasi. Ada enam literasi dasar yang disepakati dalam world economic forum pada tahun 2015 yaitu literasi baca tulis, literasi numerasi, literasi sains, literasi digital, literasi finansial dan literasi budaya dan kewargaan. Salah satu literasi yang erat kaitannya dengan kemampuan berpikir dan bernalar adalah literasi numerasi. Literasi erat kaitannya dengan bahasa, sedangkan numerasi erat kaitannya dengan matematika, sehingga literasi numerasi adalah kemampuan 
bernalar menggunakan bahasa dan matematika (GLN, 2017).

Tes yang mengukur kemampuan literasi numerasi adalah PISA dan TIMSS. PISA dan TIMSS merupakan dua organisasi di bawah OECD (Organisation for Economic Co-operation and Development). Hasil PISA dari tahun ke tahun menunjukan bahwa kemampuan literasi numerasi dari siswa di Indonesia masih rendah. Pada tahun 2015, Indonesia mendapatkan nilai matematika 387 dari nilai rata-rata 490, dan pada tahun 2018, Indonesia mendapatkan nilai matematika 379. Sedangkan TIMSS, pada tahun 2016 Indonesia memperoleh nilai matematika 395 dari rata-rata 500 (OECD, 2016; OECD, 2018). Berdasarkan hasil tersebut, Indonesia menempati posisi bawah bahkan di bawah negara kecil seperti Vietnam (Tim GLN, 2017). Hal ini disebabkan karena siswa tidak terbiasa mengerjakan soal PISA.

Hasil penelitian yang dilakukan oleh Lamada, et al (2019) menunjukan hanya 19,3\% siswa yang mampu menyelesaikan soal literasi numerasi, sedangkan sisanya berada kemampuan rendah dan sedang. Selain itu, hasil penelitian dari Tobondo, 2015 menunjukan bahwa lebih dari $70 \%$ siswa mengalami kesulitan dalam menyelesaikan soal PISA pada level 4, 5 dan 6.

Data Survei sosial dan ekonomi nasional 2018 yang dilakukan oleh BPS menunjukkan bahwa persentase penduduk di Nusa Tenggara Timur berumur 15 tahun ke atas yang melek huruf pada tahun 2018 adalah 91,90 dan pada tahun 2019 sebesar 93,24 persen. Data tersebut menunjukkan bahwa terjadi peningkatan persentase melek huruf sebesar 1,34 persen dibanding tahun 2018 (BPS dalam angka: 2020). Selanjutnya, data statistik BPS pada tahun 2019 menunjukkan bahwa salah satu dari enam Kabupaten dengan jumlah penduduk miskin tertinggi adalah kabupaten Sumba Barat Daya dengan jumlah 96.300 jiwa. Salah satu faktor yang menyebabkan kemisikinan adalah kemampuan literasi yang rendah.

Berdasarkan permasalahan di atas, peneliti terdorong untuk mengkaji lebih dalam kemampuan literasi khususnya literasi numerasi karena kompetensi dari literasi numerasi merupakan kompetensi yang umum dan mendasar dan menekankan pada kompetensi berpikir atau kemampuan seseorang dalam menggunakan penalaran. Literasi adalah kemampuan individu untuk membaca, menulis, berbicara, menghitung (UNESCO, 2008). Sedangkan numerasi adalah keterampilan mengaplikasikan konsep dan kaidah matematika dalam situasi real sehari-hari (Tim GLN, 2017), sehingga literasi numerasi adalah pengetahuan dan kecakapan untuk menggunakan berbagai macam angka dan simbolsimbol yang terkait dengan matematika dasar untuk memecahkan masalah praktis dalam berbagai macam konteks kehidupan sehari-hari; kemampuan untuk menganalisis informasi yang ditampilkan dalam berbagai bentuk grafik, tabel, bagan, dan lain-lain; dan kemampuan menggunakan interpretasi hasil analisis tersebut untuk memprediksi dan mengambil keputusan (Tim GLN, 2017). Selain itu, literasi numerasi merupakan pintu masuk untuk mata pelajaran lainnya seperti IPA, IPS, kewarganegaraan, agama, seni, dan lain-lain. 


\section{METODE}

Penelitian ini berusaha untuk mendekripsikan kemampuan peserta didik dalam menyelesaikan soal literasi numerasi sehingga penelitian ini termasuk jenis penelitian deskriptif kualitatif. Data yang diteliti berupa jawaban peserta didik atau nilai peserta didik atas soal literasi numerasi dan wawancara. Jenis penelitian kualitatif deskriptif digunakan untuk mendeskripsikan dan menggambarkan realitas mengenai suatu variabel, gejala, keadaan, atau fenomena sosial tertentu. Metode ini juga digunakan untuk menganalisis data yang diperoleh secara mendalam dan menyeluruh, sehingga tujuan penelitian tercapai. Penelitian ini dilaksanakan di sekolah menengah petama St Josef Freinadementz, Kecamatan Kota, Kabupaten Sumba Barat Daya. Subjek dalam penelitian ini adalah peserta didik kelas VIII. Fokus penelitian ini yaitu menganalisis kemampuan peserta didik kelas VIII dalam menyelesaikan soal literasi numerasi. Soal ini telah divalidasi oleh validator yang ahli dalam pendidikan matematika. Ada 3 indikator literasi numerasi yang digunakan dalam penelitian ini. Ketiga indikator tersebut adalah ketrampilan menggunakan berbagai macam angka dan simbol yang terkait dengan matematika dasar untuk memecahkan masalah dalam berbagai macam konteks kehidupan sehari-hari, kemampuan menafsirkan hasil analisis tersebut untuk memprediksi dan mengambil keputusan, dan kemampuan menganalisis informasi yang ditampilkan dalam berbagai bentuk grafik, tabel, bagan, diagram. Prosedur penelitian adalah 1) peneliti memilih subjek penelitian; 2) peneliti memberikan tes literasi numerasi; 3) peneliti mengkategorikan kemampuan siswa berdasarkan hasil tes; 4) Memilih perwakilan siswa yang wawancarai berdasarkan kategori dan mewawancarai; 5) peneliti menyimpulkan hasil penelitian. Langkah-langkah yang dilakukan untuk menganalisis data adalah reduksi data menurut Miles dan Huberman (Sugiyono, 2013). Pada penelitian ini peneliti melakukan reduksi data dimulai dari hasil tes kemampuan literasi numerasi sampai pada hasil wawancara.

\section{HASIL DAN DISKUSI}

Secara umum, hasil tes kemampuan siswa dalam menyelesaikan soal literasi numerasi dapat dilihat pada tabel berikut ini. Dari tabel 1, dapat dilihat bahwa kemampuan siswa berada pada kategori kurang dan kurang sekali.

Tabel 1. Kategori Kemampuan Literasi Numerasi Siswa

\begin{tabular}{|c|c|c|}
\hline Kategori & Banyak Siswa & Presentase Siswa (\%) \\
\hline Baik sekali & - & 0 \\
\hline Baik & - & 0 \\
\hline Cukup & - & 0 \\
\hline Kurang & 4 & 26,7 \\
\hline Kurang sekali & 11 & 73,3 \\
\hline
\end{tabular}

Berikut diuraikan soal dan perwakilan dari beberapa jawaban siswa serta analisis dari masing-masing jawaban siswa. 
Soal 1:

Akibat pemanasan global adalah mencairnya es di beberapa gletser. Dua belas tahun setelah es menghilang, tumbuhan kecil, yang disebut lumut, mulai tumbuh di bebatuan. Setiap lumut tumbuh kira-kira dalam bentuk lingkaran. Hubungan antara diameter lingkaran ini dan umur lumut dapat diperkirakan dengan rumus:

$$
d=7,0 x \sqrt{t-12}, t \geq 12
$$

dengan d melambangkan diameter lumut dalam milimeter, dan t melambangkan beberapa tahun setelah es menghilang.

a. Dengan menggunakan rumus, hitunglah diameter lumut, 16 tahun setelah es menghilang. Uraikanlah bagaimana anda mendapatkan jawabanmu.

b. Sani mengukur diameter beberapa lumut dan diameternya adalah 35 milimeter. Berapa tahun es menghilang di tempat ini? Uraikan bagaimana anda mendapatkan jawaban.

Soal ini hanya mampu dijawab dengan benar oleh 1 siswa saja. 94\% siswa tidak mampu menjawab soal ini. Berikut dilampirkan salah satu perwakilan jawaban siswa.

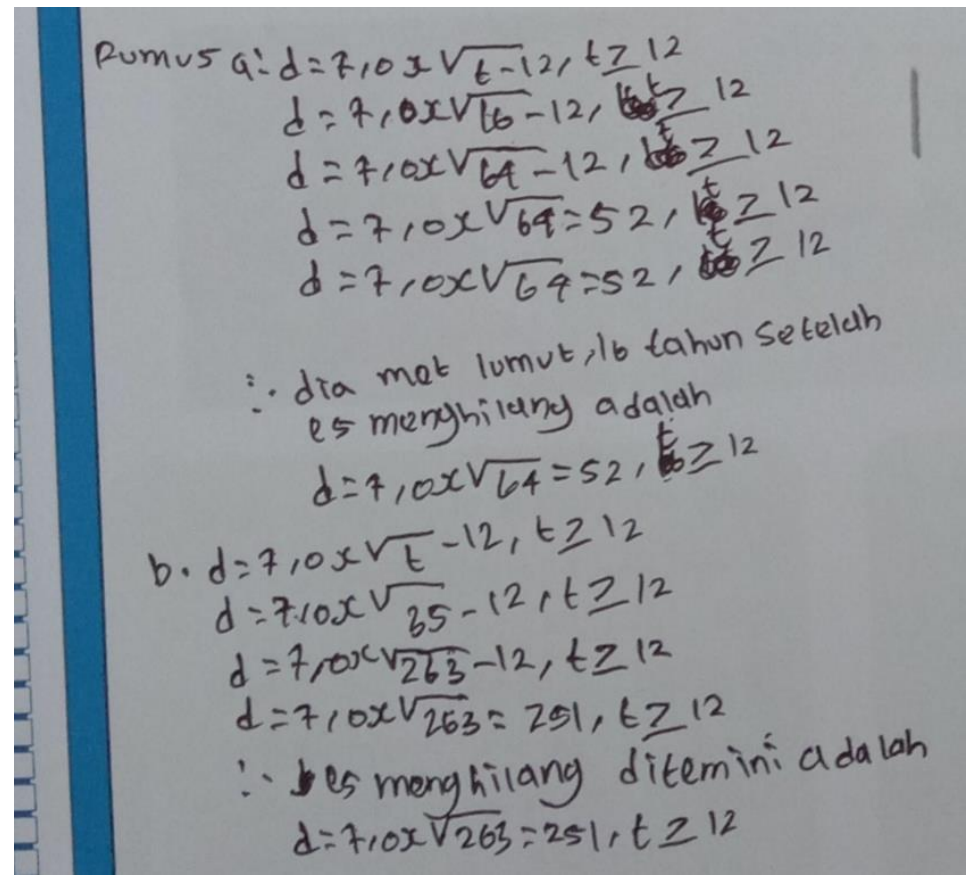

Gambar 1. Hasil Pekerjaan Subjek 1

Hasil wawancara dengan subjek 1:

P : Dari soal ini adakah kata atau kalimat yang kurang jelas?

SI : Tidak ada ibu, jelas semua

P : Paham maksud dari soal? Apa yang diketahui?

SI : Paham Ibu, yang diketahui bagian $\mathrm{a}, \mathrm{t}=16$ dan bagian $\mathrm{b}, \mathrm{D}=35$ 
P : Apa yang ditanya?

SI : Bagian a diameter dan bagian $b$ tahun

$\mathrm{P} \quad$ : Oke, jadi coba jelaskan bagaimana cara penyelesainmu?

SI : Pertama ibu, kan di soal ini sudah ada rumus, bagian a saya ganti t dengan 16 , lalu saya operasikan ibu

P : Oke, terus kenapa langkah kedua itu akar 16 - 2, lalu dilangkah ketiga menjadi akar 64 12

SI : Karena akar Ibu, jadi 16 dibagi dua sama dengan 8 terus delapan kali 8 sama dengan 64, 64 kurang 12 sama dengan 52

P : Oh oke, terus kalau akar sudah dioperasikan kenapa masih ada akar 64 disitu, kan harusnya tinggal 7 kali 52

SI : Saya bingung Ibu, karena disamping itu $t \geq 12$, mau langsung kali saya bingung itu untuk apa, jadinya saya biarkan begitu saja karena saya tidak mengerti lagi ibu.

$\mathrm{P} \quad$ : Terus yang bagian $\mathrm{b}$, kenapa menggantikan variabel $\mathrm{t}$ padahal diawal tadi adik bilang yang diketahui d dan yang ditanya $t$

SI : Saya bingung, karena t ada dalam akar, nanti kalau ganti d bagaimana cari t, jadi saya pikir mungkin $t$ juga yang diganti

P : Oh, oke kalau begitu, Terimakasih

Dari jawaban siswa dan hasil wawancara menunjukkan bahwa siswa tidak memiliki keterampilan dalam menggunakan berbagai macam angka dan simbol yang terkait dengan matematika dasar untuk memecahkan masalah dalam berbagai macam konteks kehidupan sehari-hari. Pada baris pertama siswa menulis kembali rumus yang digunakan untuk menentukan diameter lumut. Pada baris kedua, dapat dilihat bahwa siswa mensubstitusikan nilai $\mathrm{t}$ dengan benar. Kemudian pada baris selanjutnya, siswa mendapatkan hasil 64 dengan alasan bahwa 16 dibagi 2 menghasilkan 8 dan 8 dikali dengan 8 menghasilkan 64.

Berdasarkan jawaban yang diberikan, dapat dilihat bahwa siswa tidak memperhatikan dengan teliti tanda operasi yang digunakan dan angka yang tertera pada term tersebut. Hal ini juga sama dengan jawaban siswa pada baris selanjutnya, siswa mendapatkan hasil 52 karena 64 dikurangi dengan 12, meskipun bilangan ini sudah dioperasikan pada baris sebelumnya, sehingga jawaban siswa secara keseluruhan salah. Untuk jawaban dari pertanyaan b, siswa mengganti nilai $t$, meskipun yang diketahui adalah diameter lumut. Hasil wawancara menunjukan bahwa siswa kebingungan dalam mengoperasikan variabel $\mathrm{t}$ yang ada dalam tanda akar, sehingga ia menggantikan nilai $\mathrm{t}$ tersebut, meskipun ia mengetahui bahwa dari soal, yang diketahui adalah diameter. Oleh karena itu, secara umum dapat dikatakan bahwa siswa belum mampu berhitung menggunakan simbol akar yang disediakan sehingga jawaban siswa salah dan tidak sesuai dengan pertanyaan yang diminta. 
Soal 2:

Seorang tukang kayu memiliki kayu yang panjangnya 4 meter dan ingin membuat bingkai jendela. Dia mempertimbangkan beberapa desain berikut ini.

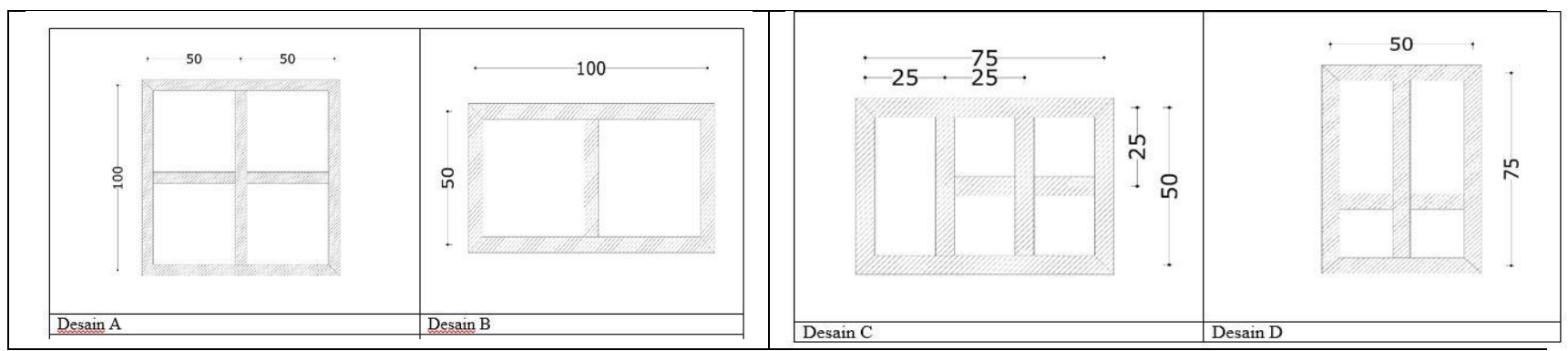

Gambar 2. Desain bingkai Jendela

Apakah desain-desain di atas dapat dibuat bingkai jendela dengan ukuran kayu tepat 4 meter?

Tabel 2. Penentuan bingkai jendela yang sesuai dengan ukuran kayu

\begin{tabular}{|l|l|l|l|}
\hline Desain Jendela & Ya & Tidak & Alasan \\
\hline Desain A & & & \\
\hline Desain B & & & \\
\hline Desain C & & & \\
\hline Desain D & & & \\
\hline
\end{tabular}

Soal ini hanya mampu dijawab oleh 1 siswa. 94\% siswa tidak mampu menjawab soal ini. Berikut dilampirkan perwakilan jawaban siswa.

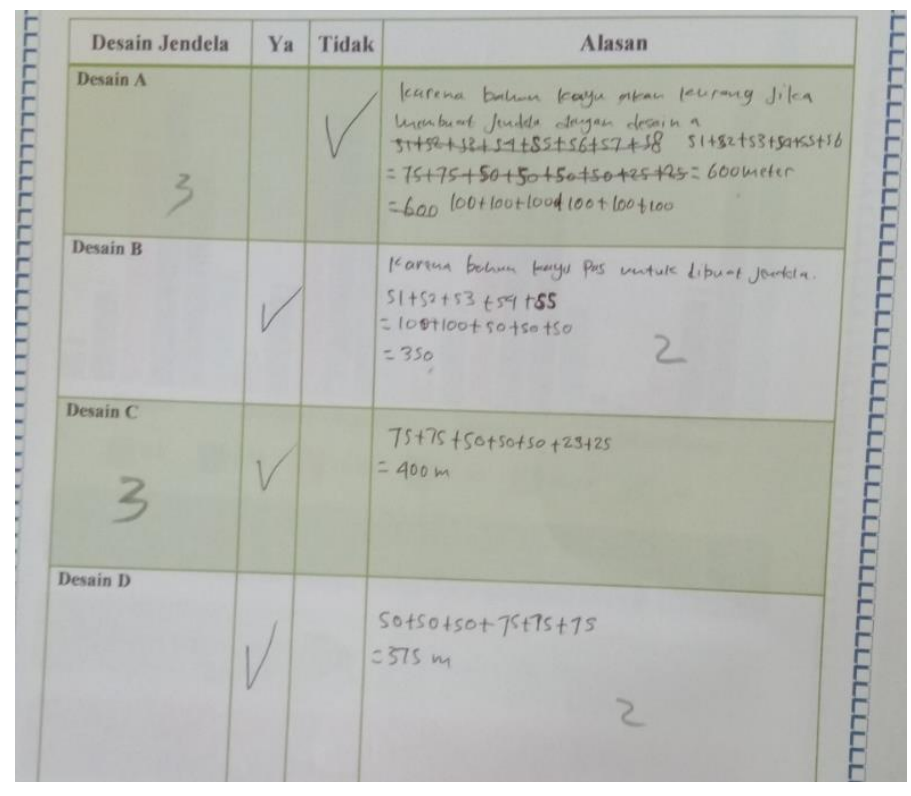

Gambar 2. Hasil Pekerjaan Subjek 2

Hasil wawancara dengan subjek 2: 
P : Dari soal ini adakah kata atau kalimat yang kurang jelas?

S V : Tidak ada ibu, jelas semua

$\mathrm{P} \quad$ : Paham maksud dari soal? apa yang diketahui?

S2 : Paham Ibu, yang diketahui panjang kayu 4 meter

P : : Terus, kenapa Johan tidak menuliskan yang diketahui

S2 : Kerja cepat-cepat ibu, karena waktu tinggal sedikit tidak sempat tulis lagi yang diketahui dan ditanya

P : Yang ditanya apa ?

S2 : Apakah desain-desain dapat dibuat bingkai dengan ukuran kayu 4 meter?

$\mathrm{P} \quad$ : Oke, terus coba jelaskan bagaimana cara penyelesaianmu?

S2 : Karena kayu yang ada 4 meter ibu sama dengan $400 \mathrm{~cm}$, jadi saya hitung dulu tiap desaindesain itu butuh berapa meter baru saya sesuaikan dengan jumlah kayu yang ada

$\mathrm{P} \quad$ : Jadi, kesimpulannya desain mana saja yang memenuhi dan desain mana yang tidak memenuhi?

S2 : Desain A tidak memenuhi Ibu, karena kayu yang dibutuhkan 6 meter sedang kayu yang dimiliki cuma 4 meter, terus desain B,C dan D itu memenuhi karena kayu 4 meter cukup untuk buat jendela desain-desain itu.

$\mathrm{P} \quad$ : Coba jelaskan menurut Johan kenapa desain B dan D itu memenuhi?

S2 : Karena kayu yang dibutuhkan untuk desain C $350 \mathrm{~cm}$ sedangkan kayu yang dimiliki $400 \mathrm{~cm}$ jadi bisa untuk buat jendela desain itu,begitu untuk desain D kayu yang dibutuhkan $375 \mathrm{~cm}$ berarti cukup juga ibu.

P : Oke baik, terimakasih

Jawaban siswa dan hasil wawancara menunjukkan bahwa siswa memahami informasi yang tertera pada soal. Siswa mampu memberi alasan untuk setiap keputusannya. Untuk desain A, siswa mencentang pada tempat yang sesuai dan memberi alasan yang tepat. Siswa mampu menghitung banyaknya kayu yang dibutuhkan untuk desain A yakni $600 \mathrm{~cm}$ atau $6 \mathrm{~m}$, sehingga ukuran kayu ini melebihi ukuran kayu yang tersedia yakni 4 meter. Untuk desain B, siswa telah menghitung ukuran bingkai jendela dengan benar yaitu 350, akan tetapi posisi centang kurang tepat karena yang diminta dalam soal desain jendela yang dapat dibuat bingkai dengan ukuran kayu tepat 4 meter. Begitu juga dengan desain D. Siswa menghitung ukuran kayu yang sesuai dengan desain D yaitu $375 \mathrm{~cm}$. Akan tetapi posisi centang masih kuran tepat, karena yang diminta dalam soal desain jendela yang dapat dibuat bingkai dengan ukuran kayu tepat 4 meter. 
Soal 3:

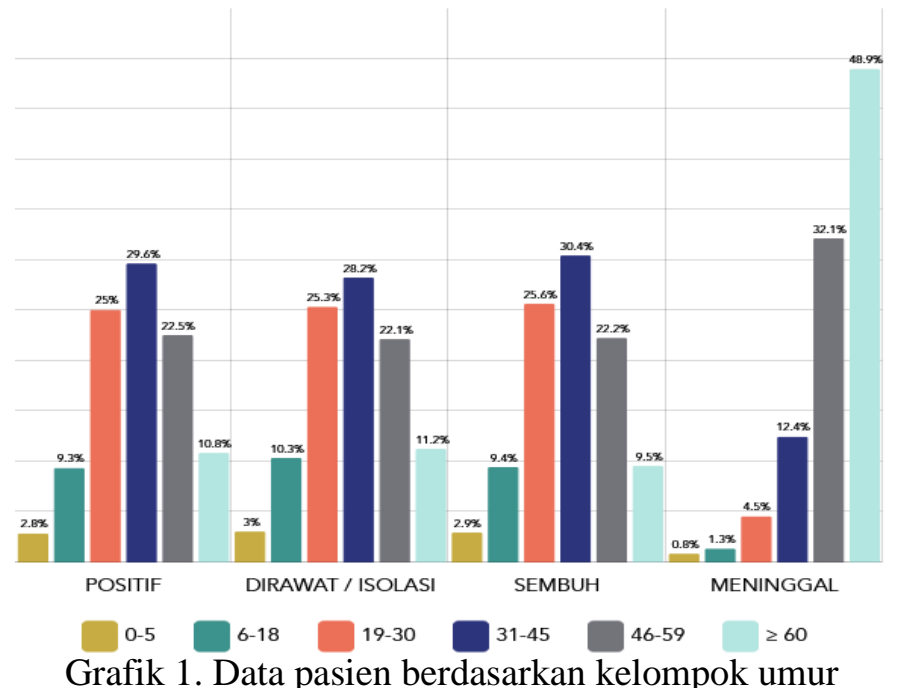

a. Urutkanlah data dari terkecil ke terbesar berdasarkan semua kasus pada kelompok umur 46-59!

b. Pada kelompok umur berapakah pasien paling banyak sembuh?

c. Berapakah rata-rata pasien dengan kasus positif, dirawat/isolasi dan sembuh pada umur 19-30?

Soal ini hanya mampu dijawab oleh 2 siswa. $87 \%$ siswa tidak mampu menjawab soal ini. Berikut dilampirkan perwakilan jawaban siswa.

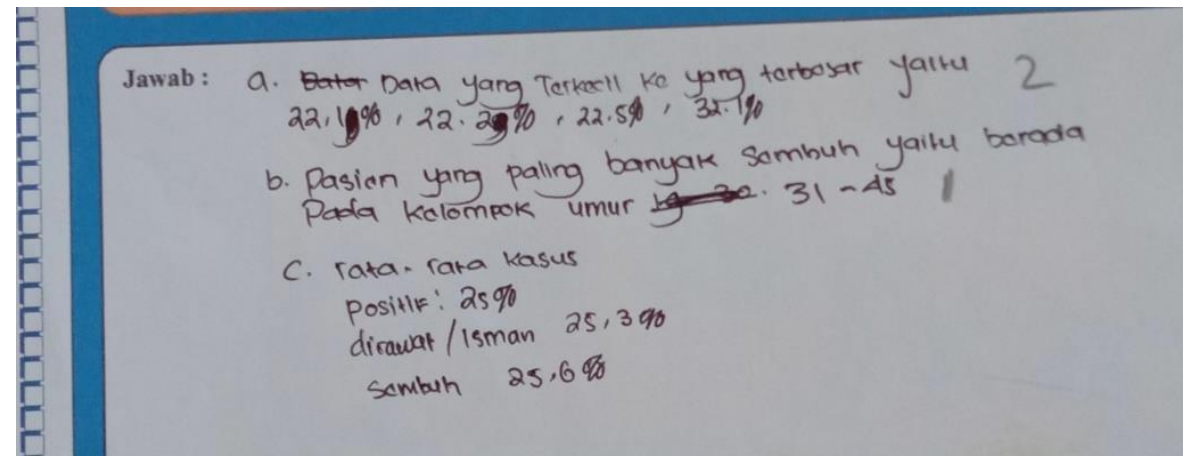

Gambar 3. Hasil Pekerjaan Subjek 3

Hasil wawancara dengan subjek 3:

P : Dari soal ini adakah kata atau kalimat yang kurang jelas ?

S3 : Tidak ada ibu, jelas semua

P : Paham maksud dari soal? apa yang diketahui?

S3 : Agak bingung ibu, menurut saya yang diketahui a itu kasus covid pada kelompok umur 46-59, bagian b pasien yang sembuh, bagian c kasus positif.

P $\quad$ : Data - data itu Dea dapatkan darimana? 


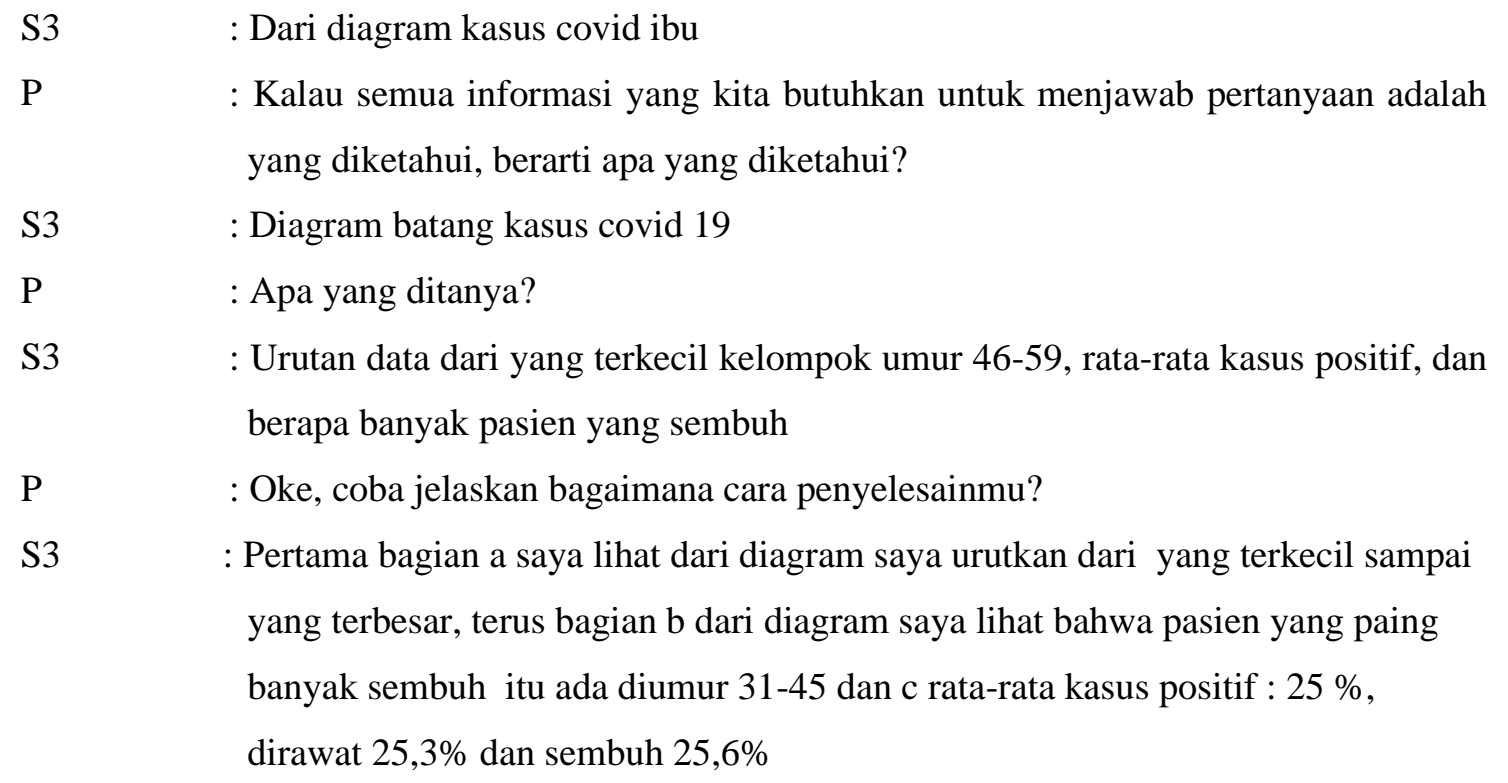

Untuk jawaban siswa dari pertanyaan a: subjek mampu mengurutkan data dari terkecil ke terbesar berdasarkan semua kasus pada kelompok umur 46-59. Begitu juga dengan jawaban dari pertanyaan pada bagian b. Siswa memahami informasi yang tertera pada diagram dengan benar, sehingga ia mampu menentukan kelompok umur dengan pasien paling banyak sembuh. Untuk jawaban dari pertanyaan bagian c, siswa tidak dapat menentukan rata-rata pasien dengan kasus positif, dirawat/isolasi dan sembuh pada umur 19-30 tahun. Siswa hanya melihat pada data masing-masing diagram dan tidak menghitung rata-rata dari ketiga diagram tersebut.

\section{Diskusi}

Hasil menunjukan bahwa hampir semua siswa tidak mampu menyelesaikan soal literasi numerasi. 73,3\% siswa berada pada kategori kurang sekali dan 26,7\% berada pada kategori kurang. Kesulitankesulitan yang dialami oleh siswa dijelaskan seperti berikut: soal dengan indikator 1 yaitu Keterampilan menggunakan berbagai macam angka dan simbol yang terkait dengan matematika dasar untuk memecahkan masalah dalam berbagai macam konteks kehidupan sehari-hari. Siswa mengalami kesulitan dalam memaparkan informasi mengenai apa yang diketahui dan ditanyakan pada soal. Siswa tidak mampu melakukan operasi perhitungan dasar dan menggantikan variabel dengan bilangan yang sesuai dengan yang diminta pada soal. Hal ini terlihat dari perwakilan jawaban siswa pertama. Temuan ini sejalan dengan penelitian dari Sidik, dkk, 2019 yang mengatakan bahwa siswa kesulitan dalam menerjemahkan maksud soal ke dalam model matematika yang sudah ada. Kemudian, Muncarno (Sudirman, dkk, 2019) siswa kesulitan dalam mengerjakan soal cerita karena siswa kurang teliti dan cermat dalam membaca dan memahami kalimat demi kalimat, dan siswa kesulitan memahami apa yang diketahui dan ditanyakan pada soal serta cara penyelesaiaanya

Untuk indikator 2, soal nomor 2 dengan indikator kemampuan menafsirkan hasil analisis untuk memprediksi dan mengambil keputusan. Soal ini membutuhkan kemampuan penalaran yang tinggi. Siswa harus memahami makna matematika dari bingkai jendela. Kesulitan yang dialami oleh siswa adalah siswa tidak mampu memilih strategi apa yang digunakan untuk memecahkan masalah tersebut 
atau dengan kata lain siswa kesulitan dalam memahami dan menerapkan konsep luas dan keliling. Hal ini sejalan dengan penelitian yang dilakukan oleh Fauzi, dkk 2020, Juanti, dkk, 2021 yang mengatakan bahwa siswa kesulitan dalam memahami konsep yaitu siswa tidak dapat memilih rumus apa yang digunakan untuk menyelesaikan masalah tersebut.

Untuk indikator 3, soal nomor 3 dengan indikator menganalisis informasi yang ditampilkan dalam berbagai bentuk grafik, tabel, bagan, diagram. 2 dari 15 siswa mampu menjawab soal ini dengan benar. Mereka mampu menuliskan jawaban sesuai dengan soal. Sisanya, tidak mampu menjawab soal tersebut. Hal ini disebabkan karena siswa tidak mampu membaca dan memahami data yang tertera dalam diagram. Hal ini sejalan dengan penelitian dari Koparan, 2015 yang mengatakan bahwa siswa mengalami kesulitan terkait dengan representasi dari data yakni tidak dapat membaca data yang ditampilkan dalam tabel.

Dari ketiga indikator tersebut, dapat dikatakan bahwa siswa tidak mampu mengerjakan soal literasi numerasi dikarenakan siswa jarang sekali mengerjakan soal yang seperti itu. Soal yang biasa diberikan hanyalah soal yang menggunakan perhitungan semata seperti hitunglah, tentukanlah atau soal yang hanya menerapkan rumus secara langsung. Hal ini sejalan dengan pendapat dari Wardani (2011) yang mengatakan bahwa siswa tidak terbiasa mengerjakan soal-soal yang membutuhkan kemampuan penalaran yang tinggi sehingga siswa mengalami kesulitan untuk menyelesaikannya; siswa belum memiliki kemampuan berpikir kiritis dan bernalar yang optimum (Manggala, 2015). Salah satu cara untuk mengembangkan kemampuan berpikir kritis siswa adalah guru harus memiliki kompetensi dalam memilih, merancang, mengembangkan pembelajaran dan memfasilitiasi siswa agar siswa berlatih untuk berpikir kritis (Irawan, dkk, 2017). Selain itu, agar kemampuan literasi siswa meningkat, maka kualitas pembelajaran dapat diarahkan melalui akitivitas metakognitiv antara siswa dan guru yang berlangsung selama pembelajaran (Ate, 2021). Rendahnya hasil siswa dalam mengerjakan soal tes literasi mungkin juga dipengaruhi oleh pola belajar siswa di sekolah diakibatkan oleh pandemi Covid-19, sehingga siswa tidak secara penuh melakukan proses pembelajaran di sekolah akan tetapi melakukan pembelajaran daring di rumah.

\section{KESIMPULAN}

Berdasarkan hasil dan pembahasan yang telah dipaparkan dapat disimpulkan bahwa kemampuan litreasi numerasi siswa masih berada pada kategori kurang dan kurang sekali dengan rincian: kemampuan siswa pada indikator 1 yaitu keterampilan menggunakan berbagai macam angka dan simbol yang terkait dengan matematika dasar untuk memecahkan masalah dalam berbagai macam konteks kehidupan sehari-hari berada pada kategori kurang sekali, kemampuan siswa pada indikator 2 berada pada kategori kurang sekalidan indikator 3 berada pada kategori kurang. Oleh karena itu, peneliti menyarankan agar dapat dijadikan bahan evalusi oleh guru sehingga guru dapat mengembangkan soal literasi numerasi dan melatih siswa untuk menyelesaikan soal yang telah dikembangkan. 


\section{UCAPAN TERIMA KASIH}

Peneliti mengucapkan terima kasih kepada Kemenristek Dikti yang telah memberikan bantuan dana hibah penelitian sehingga penelitian ini dapat terlaksana dengan baik. Peneliti juga mengucapkan terima kasih kepada Ketua Yayasan Pendidikan Nusa Cendana dan Ketua Sekolah Tinggi Keguruan dan Pendidikan Weetebula yang telah membantu peneliti sehingga dapat melakukan penelitian.

\section{REFERENSI}

Ate, D. (2021). Enhancing Primary School Students' Competencies in Step by Step controllable argumentation. Jurnal Riset Pendidikan Matematika, 8(1), 73-82. doi:https://doi.org/10.21831/jrpm.v8i1.3532

BPS Dalam Angka. (2020). Provinsi Nusa Tenggara Timur Dalam Angka. Kupang, BPS Provinsi NTT.

Fauzi, I., \& Arisetyawan, A. (2020). Analisis Kesulitan Belajar Siswa pada Materi Geometri di Sekolah Dasar. (U. N. Semarang, Hrsg.) Jurnal Matematika Kreatif-Inovatif, 1(11), 27-35. doi:http://dx.doi.org/10.15294/kreano.v11i1.20726

Irawan, T. A., Rahardjo, S. B., \& Sarwanto. (2017). Analisis Kemampuan Berpikir Kritis Siswa Kelas VII-A SMP Negeri 1 Jaten. Prosiding Seminar Nasional Pendidikan Sains, 232-236. Von http://www.jurnal.fkip.uns.ac.id/index.php/snps/article/viewFile/11418/8103 abgerufen

Juanti, S., Karolina, R., \& Zhanty, L. S. (2021). Analisis Kesulitan Siswa dalam Menyelesaikan Soal Geometri Pokok Bahasan Bangun Ruang Sisi Datar. (P. I. MS, Hrsg.) Jurnal Pembelajaran Matematika Inovatif, 4(2), 239-248. doi:https://DOI 10.22460/jpmi.v4i2.239-248

Koparan, T. (2015). Difficulties in Learning and Teaching Statistics: Teacher Views. (E. T. Francis, Hrsg.) International Journal of Mathematical Education in Science and Tecnhology, 1(46), 94-104. doi:http://dx.doi.org/10.1080/0020739X.2014.941425

Lamada, M., Rahman, E. S., \& Herawati. (2019). Analisis Kemampuan Literasi Numerasi Siswa SMK Negeri di Kota Makassar. Jurnal Media Komunikasi Pendidikan Teknologi dan Kejuruan, 6(1), 35-42.

Manggala, I. S. (2015). Peningkatan Literasi Matematis dan Self-Esteem Siwa SMP Melalui Pembelajaran Concrete. Universitas Pendidikan Indonesia:repository.upi.edu.

OECD. (2016). PISA Result in Focus. Paris: OECD Publishing.

OECD. (2018). PISA Result in Focus. Paris: OECD Publishing.

PG Dikdas. (2020). Literasi dan Numerasi adalah Kompetensi yang Bersifat Mendasar. Von http://pgdikdas.kemdikbud.go.id/read-news/literasi-dan-numerasi-adalah-kompetensi-yang berdifat-mendasar. abgerufen

Polya, G. (1957). A New Aspect of Mathematical Method. USA: Princeton University Press.

Sidik, S. G., \& Wakih, A. A. (2019). Kesulitan Belajar Matematika Siswa SD pada Operasi Hitung Bilangan Bulat. Jurnal Kajian Penelitian dan Pendidikan dan Pembelajaran, 4(1), 461-470.

Sudirman, S., Cahyono, E., \& Kadir, K. (2019). Analisis Kemampuan Koenksi Matematis Siswa SMP Pesisir Ditinjau Dari Perbedaan Gender. Jurnal Pembelajaran Berpikir Matematika, 3(2).

Sugiyono. (2013). Metode Penelitian Pendidikan Pendekatan Kuantitatif, Kualitatif, dan $R \&$ D. Bandung: Alfabeta. 
Tim Gerakan Literasi Nasional. (2017). Materi Pendukung Literasi Numerasi. Jakarta: Kementrian Pendidikan dan Kebudayaan.

Tobondo, F. A. (2015). Deskripsi kemampuan literasi matematis kelas VIIIb di SMP Kalam Kudus. Skripsi tesis. Yogyakarta: Universitas Sanata Dharma.

UNESCO Institute for Statistics. (2008). International literacy statistics: A review of concepts, methodology, and current data. Montreal, Canada: UNESCO Institute for Statistics.

Wardani, S., \& Rumiati. (2011). Instrumen Penilaian Hasil Belajar Matematika SMP: Belajar dari PISA dan TIMMS. Yogyakarta: P4TK Matematika Kementrian Pendidikan Nasional. 